\title{
EMPRESÁRIO INDIVIDUAL E A INTERFERÊNCIA DO REGIME MATRIMONIAL DE BENS NA ATIVIDADE EMPRESARIAL À LUZ DO ARTIGO 978 DO CÓDIGO CIVIL
}

INDIVIDUAL EMPLOYEE AND THE INTERFERENCE OF THE MATRIMONIAL REGIME OF GOODS IN THE BUSINESS ACTIVITY IN THE LIGHT OF ARTICLE 978 OF THE CIVIL CODE

\section{Larissa Marim da Costa ${ }^{1}$}

ISSUE DOI: $10.21207 / 1983.4225 .399$

\section{RESUMO}

O novo Código Civil trouxe relevantes modificações, principalmente, no tocante às relações empresariais e conjugais. Frente a essas modificações tem-se a regra específica do artigo 1.647, I do Código Civil, o qual proíbe a alienação de bens do cônjuge casado sem a devida autorização do outro, porém essa regra não pode ser aplicada ao empresário, pois, o artigo 978 do Código Civil, prevê a dispensa da outorga conjugal para a alienação ou oneração de bens imóveis destinados à atividade empresarial, qualquer que

\footnotetext{
${ }^{1}$ Bacharel em Direito pela Faculdade de Direito de Franca (2016); Estudante no Mestrado Profissiona da Faculdade de Ciências Humanas e Sociais - UNESP (2017-2018); Iniciação Científica pela Faculdade de Direito de Franca (2014/2015); Monitora na disciplina de Direito Administrativo; Estágio profissional na Área de Direito em Escritório de AdvocaciaPrior Advogados (2014); Estágio profissional na Área de Direito em Escritório de Advocacia - Pádua Faria Sociedade de Advogados (2015-2016); Trainee no escritório de advocacia "Barreiros \& Santos Advogados" (2017-até o momento).
} 
seja o regime de bens, para o empresário individual casado. Posto isso, necessária é a análise do regime de bens no casamento, bem como o regime jurídico do empresário individual, para posteriormente se abordar as questões inerentes à dispensa da outorga conjugal no ordenamento jurídico brasileiro. Nesse diapasão, é a partir da análise do regime de bens, o qual perdura no casamento que se conhece às limitações e imposições legais aos cônjuges perante determinados atos de conteúdo patrimonial. Enfim, a partir da inovação do artigo 978 do Código Civil, a qual permite ao cônjuge empresário praticar atos sem a anuência do outro, pretender-se-á com o presente estudo demonstrar a necessidade de verificar a possibilidade ou não da sua aplicação, o que se fará a partir do encontro das temáticas do direito de família e do direito de empresa e, inclusive, sob o enfoque jurisprudencial da proteção do patrimônio da família. No que tange a metodologia utilizada no trabalho, foram adotados os seguintes métodos: método comparativo, método dialético, estudo dogmático-jurídico, estudo metodológico histórico, método dedutivo e método indutivo.

Palavras-Chave: Empresário individual. Outorga. Alienação de bens. Regime de bens. Capacidade.

\section{ABSTRACT}

The new Civil Code brought important changes, mainly, not touching as business and marital relations. In view of these changes, there is a specific rule of article 1,647, Civil jurisdiction code, which prohibits the alienation of married spouses' property without proper authorization from the other. For, Article 978 of the Civil Code provides for a dispensation Of the marital orgasm for a disposal or maintenance of real estate is intended for business activity, whatever the property regime, for the individual married businessman. Having said this, it is an analysis of the regime of goods without marriage, as well as the legal regime of the individual prisons, to later be addressed as ineffective issues in the exemption of conjugal conjugation in the Brazilian legal system. In this context, from the analysis of the property regime, which in marriage is known to the legal limitations and impositions imposed on the spouses before certain acts of patrimo-nial content. Finally, from the innovation of article 978 of the Civil Code, an applicant for authorization to exercise a non-profit employment contract. Regarding the 
methodology used in the work, the following methods were adopted: comparative method, dialectical method, dogmatic-juridical study, historical methodological method, deductive method and inductive method.

Keywords: Individual entrepreneur. Grant. Alienation of goods. Regime of goods. Capacity.

\section{INTRODUÇÃO}

Com o advento do novo Código Civil houve a unificação (parcial) do direito privado, tendo sido revogada expressamente a primeira parte do Código Comercial de 1850. Contudo, mantém o direito empresarial autonomia em relação ao direito civil.

Assim sendo, tem-se como ponto de partida o conceito de empresário, o qual é a pessoa física que exerce atividade empresarial, ou seja, exerce a atividade econômica organizada, conforme artigo 966 do Código Civil: "Considera-se empresário quem exerce profissionalmente atividade econômica organizada para a produção ou a circulação de bens ou de serviços".

A exceção desse artigo, conforme seu parágrafo único preceitua, retira a qualidade de empresário aos que exercem profissão intelectual, de natureza científica, literária ou artística, ainda com o concurso de auxiliares ou colaboradores, salvo se o exercício da profissão constituir elemento de empresa.

Pelo perfil subjetivo tem-se o empresário que pode ser uma pessoa física, a qual é o empresário individual, ou uma pessoa jurídica, uma sociedade. Ou seja, para exercer a atividade empresarial ou é qualificado como empresário individual ou é considerado como uma das modalidades de sociedade empresária.

Nesse diapasão, é permitido a qualquer dos cônjuges exercer a atividade empresarial sob uma firma individual, o que, consequentemente, faz recair uma responsabilidade ilimitada pelas obrigações contraídas.

Desse modo, há a identidade do patrimônio do empresário individual (patrimônio empresarial) com o seu patrimônio pessoal (pessoa natural).

Reitera-se que o empresário individual exerce a atividade empresarial mediante firma individual e a esse não é concedido personalidade 
jurídica distinta da pessoa natural, por consequência, o patrimônio pessoal (pessoa natural) se confunde com o patrimônio empresarial, ou seja, tornam-se uma única unidade. Logo, não há que se falar no patrimônio da empresa, a princípio, porque o patrimônio é uno e diz respeito à pessoa natural, sujeito de direitos e deveres.

Ocorre que o legislador lançou mão do art. 978 do Código Civil para ampliar a liberdade do empresário na disposição do patrimônio empresarial, objetivando, assim, estimular o desenvolvimento das atividades empresariais.

Dessa forma, prevê o artigo supra que: "O empresário casado pode, sem necessidade de outorga conjugal, qualquer que seja o regime de bens, alienar os imóveis que integrem o patrimônio da empresa ou graválos de ônus real".

Da leitura do artigo verifica-se o conflito entre o direito empresarial e o direito de família, o qual passou a existir com a vigência do artigo 978 do Código Civil.

Nesse passo, o art. $1.647^{2}$ do Código Civil dispõe expressamente a necessidade da outorga do cônjuge, salvo no regime de separação de bens, para a disposição dos bens imóveis, seja para alienar, seja para gravar de ônus real, de acordo com o seu inciso I.

Ainda, o inciso I do art. $1.642^{3}$ do C.C. reitera a importância do bem imóvel como patrimônio da família ao impedir a sua alienação ou oneração mesmo quando se tratar do exercício da atividade profissional.

Logo, frente ao exposto, surgem as seguintes indagações:

Seria o art. 978 do CC uma exceção ao art. 1.647, I do CC, o qual impede o cônjuge não empresário de decidir sobre o destino do bem imóvel pertencente ao patrimônio familiar?

\footnotetext{
2 Art. 1.647. Ressalvado o disposto no art. 1.648, nenhum dos cônjuges pode, sem autorização do outro, exceto no regime da separação absoluta: I - alienar ou gravar de ônus real os bens imóveis. In: BRASIL. Lei no 10.406, de 10 de janeiro de 2002. Disponível em: <http://www.planalto.gov.br/ccivil_03/LEIS/2002/L10406.htm>. Acesso em: 15. Dez. 2015.

${ }^{3}$ Art. 1.642. Qualquer que seja o regime de bens, tanto o marido quanto a mulher podem livremente: I - praticar todos os atos de disposição e de administração necessários ao desempenho de sua profissão, com as limitações estabelecidas no inciso I do art. 1.647. In: BRASIL. Lei no 10.406, de 10 de janeiro de 2002. Disponível em: <http://www.planalto.gov.br/ccivil_03/LEIS/2002/L10406.htm>. Acesso em: 15. Dez. 2015.
} 
Pode-se aceitar a dispensa da outorga na situação prevista do art. 978 do CC quando a meação do cônjuge não empresário pode vir a ser ameaçada por uma dívida do empresário?

Frente às diversas indagações que rodeiam o art. 978 do Código Civil é que se faz pertinente o estudo do regime de bens no casamento e, a administração e a disponibilidade do patrimônio da sociedade conjugal frente à confusão entre o patrimônio do empresário e o patrimônio pessoal (pessoa natural), uma vez que o patrimônio do empresário é uno.

$\mathrm{O}$ intuito maior da pesquisa é analisar o tema e seus impactos dentro do Direito e da sociedade no Brasil, por isso através do método comparativo far-se-á um estudo comparado do código anterior ao nosso atual ordenamento jurídico, contrastando-os entre si e com os diferentes fundamentos e concepções que imperam em diversos lugares e culturas.

Serão empreendidos também o método dialético, gerador da discussão e da argumentação, e o estudo dogmático-jurídico, que analisa a lei, a jurisprudência e a doutrina, fazendo analogias e interpretações.

O estudo metodológico histórico através do método dedutivo dará noções da dimensão do tema mais próximas da realidade a partir da abordagem de sua evolução histórica e o método indutivo será aplicado nas análises e conteúdos contemplados pelo direito constitucional e civil.

\section{CONCEITO DE EMPRESÁRIO}

Empresário é a pessoa física que exerce atividade empresarial, ou seja, exerce a atividade econômica organizada. Conforme artigo 966 do Código Civil: "Considera-se empresário quem exerce profissionalmente atividade econômica organizada para a produção ou a circulação de bens ou de serviços".

Assim, a característica primordial inerente ao empresário é a habitualidade do exercício da atividade econômica organizada com o escopo de lucro.

A exceção desse artigo, conforme seu parágrafo único preceitua, retira a qualidade de empresário aos que exercem profissão intelectual, de natureza científica, literária ou artística, ainda com o concurso de auxiliares ou colaboradores, salvo se o exercício da profissão constituir elemento de empresa. 


\subsection{EMPRESÁRIO INDIVIDUAL}

A par do conceito de empresário, o empresário individual seria justamente a pessoa física, titular da empresa.

Nas palavras de Sérgio Campinho:

O exercício da empresa pelo empresário individual se fará sob uma firma individual, constituída a partir de seu nome, completo ou abreviado, podendo a ele ser aditado designação mais precisa de sua pessoa ou do gênero de atividade. Nesse exercício, ele responderá com todas as forças de seu patrimônio pessoal, capaz de execução, pelas dívidas contraídas, vez que o Direito Brasileiro não admite a figura do empresário individual com responsabilidade limitada e, consequentemente, a distinção entre patrimônio empresarial (o patrimônio do empresário individual afetado ao exercício de sua empresa) e patrimônio particular do empresário, pessoa física. ${ }^{4}$

Como preceitua Mônica Gusmão:

O empresário individual é a pessoa física que se obriga através de seu próprio nome, responde com seus bens pessoais, assume responsabilidade ilimitada, incide pessoalmente em falência e pode pleitear sua recuperação judicial ou extrajudicial. ${ }^{5}$

O empresário para ser considerado regular, deverá se inscrever no Registro Público de Empresas Mercantis da respectiva sede, a cargo de Juntas Comerciais, antes de iniciar a sua atividade econômica.

${ }^{4}$ CAMPINHO, Sérgio. $\mathrm{O}$ direito de empresa à luz do novo código civil. Rio de Janeiro: Renovar, 2009. p. 12.

${ }^{5}$ GUSMÃO, Mônica. Curso de direito empresarial. Rio de Janeiro: Lumen Juris, 2007. p. 58 . 
Não há que se confundir a figura do empresário individual com o sócio de uma sociedade empresária, bem como com o profissional autônomo, uma vez que, o sócio não é empresário, mas sim um integrante de uma sociedade empresária.

No tocante ao profissional autônomo, é importante ressaltar que a característica primordial que o distingue do empresário individual é que esse baseia sua atividade profissional em uma organização que compreende a articulação, a ordenação do trabalho e meios materiais, podendo ser ela de pequena monta ou de grande expressão, ao passo que aquele, não baseia sua atividade profissional nessas características.

Nesse sentido, complementa Sérgio Campinho:

Assim é que, por exemplo, o pipoqueiro ou o vendedor de águas-de-coco em uma "carrocinha" não pode ser visto como empresário, mas sim como um vendedor autônomo. Todavia, se uma pessoa natural adquire algumas "carrocinhas" e as equipa para venda de pipocas ou águas-de-coco, contratando pessoas para operar as vendas, criando elementos distintivos de seus produtos, ter-se-á o explorador dessa atividade como empresário, pois exerce atividade econômica organizada, ainda que, o padrão de organização seja de pequeno vulto, ainda que a atividade revele negócio de pequeno porte. ${ }^{6}$

Assim sendo, o empresário individual não possui responsabilidade limitada e, tampouco pode ser confundido com o sócio de uma sociedade empresária ou com um profissional autônomo, pois são figuras distintas.

Ademais, como explanado, o patrimônio empresarial do empresário individual se confunde com o seu patrimônio particular, uma vez que esse possui responsabilidade ilimitada perante as obrigações contraídas.

\footnotetext{
${ }^{6}$ CAMPINHO, Sérgio. $\mathrm{O}$ direito de empresa à luz do novo código civil. Rio de Janeiro: Renovar, 2009. p. 13.
} 


\subsection{EMPRESÁRIO INDIVIDUAL CASADO}

No que tange ao empresário individual, a empresa é apenas parte de seu patrimônio (dele, pessoa natural), podendo esse ser alcançado por obrigações assumidas fora das atividades empresariais e, dessa forma alcançar bens e direitos, inclusive em nome do cônjuge, conforme for o regime da comunhão de bens adotado pelo casal.

O artigo 1.647 do Código Civil dispõe que nenhum dos cônjuges pode, sem autorização do outro, exceto no regime da separação absoluta: I - alienar ou gravar de ônus real os bens imóveis; II - pleitear, como autor ou réu, acerca desses bens ou direitos; III - prestar fiança ou aval; IV - fazer doação, não sendo remuneratória, de bens comuns, ou dos que possam integrar futura meação.

Presume-se que frente ao aludido artigo, o legislador pretendeu proteger o patrimônio comum do casal, sempre que os cônjuges optarem pelo regime da comunhão universal de bens ou pelo regime parcial de bens.

Quando não houver autorização do outro cônjuge (marital ou uxória) para a prática de algum ato em que dependa do consentimento dos dois, ocorrerá anulabilidade do ato, conforme artigo 1.649 do Código Civil.

Conforme Gladston Mamede:

Com facilidade se percebe que tal norma, se aplicada ao Direito de Empresa, conduziria à necessidade de que a empresa individual, sendo casado o empresário, fosse submetida a entraves em suas atividades, tornando-a uma instância do Direito de Família, designadamente da administração comum dos bens do casal. O legislador, contudo, preferiu retirar a empresa dessa administração comum, mui provavelmente para facilitar sua administração. Assim, o artigo 978 do Código Civil, permitiu ao empresário casado alienar os imóveis que integrem o patrimônio da empresa ou gravá-los de ônus real, sem necessidade de outorga conjugal, qualquer que seja o regime de bens do casal. ${ }^{7}$

\footnotetext{
${ }^{7}$ MAMEDE, Gladston. Empresa e atuação empresarial. São Paulo: Atlas, 2004. p. 85.
} 
Entretanto, se o artigo 978 do Código Civil afasta a interferência do cônjuge da administração societária, mesmo quando implique na prática de qualquer dos atos implícitos no artigo 1647 do $\mathrm{CC}$, no que tange ao empresário individual, um entrave se coloca.

Gladston Mamede complementa ainda que:

É preciso estar atento para o fato de que a licença do artigo 978 do Código Civil alcança expressamente o inciso I do artigo 1647 do Código Civil e, implicitamente, o inciso II, dispensando a presença do cônjuge para pleitear, como autor ou réu, acerca de bens imóveis e direitos a eles referentes. Não alcança, entretanto, os outros dois incisos do artigo 1647, em nada referidos (expressa ou implicitamente) pelo dispositivo. Dessa forma, mantém-se o direito do cônjuge de pleitear a anulação do aval e da fiança por ele não autorizados, bem como da doação de bens comuns, ou dos que possam integrar futura meação, não sendo remuneratória (dação em pagamento, conforme os artigos 356 e seguintes do Código Civil). 8

Nesse diapasão, a empresa corresponde, por exigência legal, a uma escrituração e expressão contábil do patrimônio especificamente próprio da empresa.

Assim, embora a empresa seja parte do patrimônio da pessoa natural que é o empresário individual, podendo se comunicar com o patrimônio de seu cônjuge, conforme o regime escolhido, a gerência daquela parcela específica da empresa foge à regra do artigo 1647, I, do CC e, dessa forma resulta em uma contraposição de artigos, o qual será nosso objeto de estudo.

\subsection{INSCRIÇÃO NA JUNTA COMERCIAL}

O exercício de atividade empresarial por parte da pessoa física ou jurídica pressupõe o registro correspondente, feito nos moldes da Lei

\footnotetext{
${ }^{8}$ MAMEDE, Gladston. Empresa e atuação empresarial. São Paulo: Atlas, 2004. p. 86.
} 
8.934, de 18 de novembro de 1994, a qual preceitua o registro público de empresas mercantis e atividades afins. Respeitando assim, o artigo 1.150 do Código Civil, o qual dispõe que o empresário e a sociedade empresária vinculam-se ao Registro Público de Empresas Mercantis a cargo das Juntas Comerciais. Dessa forma, somente as sociedades simples estarão sujeitas ao Registro Civil das Pessoas Jurídicas.

O registro público é uma forma de preservação de informações consideradas vitais para a sociedade, como nascimento, óbito, criação de pessoas jurídicas, entre outros, objetivando-se assim, dar publicidade necessária para a segurança das relações interindividuais.

\subsection{A RESPONSABILIDADE ILIMITADA DO EMPRESÁRIO INDIVIDUAL}

Tendo em vista que há uma ausência de desdobramento de personalidade jurídica, uma vez que, o empresário individual responde integralmente pelas dívidas contraídas, seja em razão de obrigação decorrente da atividade empresarial, seja de obrigação advinda do âmbito pessoal. A característica da responsabilidade ilimitada é a causadora das diversas tentativas de se escapar do regime jurídico em tela.

Segundo Sérgio Campinho:

O exercício da empresa pelo empresário individual fará com que ele responda com todas as forças de seu patrimônio pessoal, capaz de execução, pelas dívidas contraídas, vez que o Direito brasileiro não admite a figura do empresário individual com responsabilidade limitada e, consequentemente, a distinção entre patrimônio empresarial (o patrimônio do empresário individual afetado ao exercício de sua empresa) e o patrimônio particular do empresário, pessoa física. ${ }^{9}$

Nesse passo, verifica-se que a responsabilidade ilimitada do empresário individual está intrinsecamente ligada à questão da ausência de

\footnotetext{
${ }^{9}$ CAMPINHO, Sérgio. $\mathrm{O}$ direito de empresa à luz do novo código civil. Rio de Janeiro: Renovar, 2009. p. 56.
} 
personalidade jurídica da firma individual no tocante à atividade empresarial.

Assim, não existe distinção do patrimônio da pessoa natural e do empresário individual (da empresa), pois, na verdade, o que ocorre é a distinção para o fim da atividade, mas o patrimônio é considerado, até então, uma unidade só, uma vez que, não há o desdobramento da personalidade jurídica, havendo assim, uma unidade de patrimônio, a qual a pessoa natural se responsabilizará pelas obrigações civis e comerciais com a totalidade do seu patrimônio.

Logo, conclui-se que não há no direito brasileiro a personalização da firma individual, acarretando dessa forma, a ausência de distinção entre o patrimônio da pessoa natural frente ao patrimônio do empresário individual, o que enseja na responsabilidade ilimitada dessa forma de exercício da atividade empresarial.

\section{DAS DISPOSIÇÕES GERAIS SOBRE OS REGIMES DE BENS}

Essas disposições estão previstas no Capítulo I do Subtítulo I- Do Regime de Bens entre os cônjuges e compõem o Título II- Do Direito Patrimonial, abrangendo desde o artigo 1.639 até o 1.652 do Código Civil.

Essas disposições visam à concessão de variedade e liberdade dos pactos antenupciais, bem como a mutabilidade do regime na constância do casamento, e, sem dúvida, representam um grande avanço sobre o Código Civil de 1916.

De acordo com José Antônio Encinas Manfré:

Ademais, essas disposições gerais (arts. 1.639 1.652) antecedem as específicas dos diferentes regimes matrimoniais, às quais indistintamente se aplicam, além de, como aludido, preverem a respeito de administração, gozo e propriedade dos bens, assim 
como tratarem da disponibilidade destes e das dívidas que cada cônjuge possa ou não contrair. ${ }^{10}$

Sobretudo, é válido ressaltar que embora muitas regras do Novo Código Civil não sejam estranhas ao Código Civil de 1916, o atual disposto está envolto pelo influxo inovador da Constituição da República de 1988, principalmente no tocante ao tratamento isonômico entre os cônjuges (art. $226, \S 5^{\circ}{ }^{\circ}$.

Como ensina José Antônio Encinas Manfré:

Com efeito, expressando acerca de atos a ser livremente praticado pelos cônjuges, qualquer que seja o regime de bens, esse novo estatuto, nos seis incisos do artigo 1.642, além de reger vários dos assuntos antes contemplados no art. 248 do estatuto revogado, não mais se restringe especificamente à mulher e às hipóteses nas quais podia ela agir sem autorização do marido. ${ }^{11}$

O artigo 1.639 amplia a liberdade de escolha dos cônjuges, diante da variedade de regimes de bens estipulados pelo ordenamento jurídico brasileiro, antes de celebrado o casamento.

A única exceção a essa liberdade dos cônjuges é no tocante ao Regime da Separação Obrigatória, uma vez que se diz obrigatória à separação, pois essa é imposta pelo ordenamento jurídico em razão da existência de motivo de ordem pública para tanto. Por esse motivo é que se tem a exceção ao princípio de liberdade dos pactos antenupciais.

Porém, se os cônjuges não acordarem quanto ao regime de bens, ou sendo a escolha nula ou ineficaz, o regime que recairá sobre os bens será o Regime da Comunhão Parcial de bens, conforme artigo 1.640 do Código Civil.

Independentemente do Regime optado pelos cônjuges, o artigo 1.642 do Código Civil dispõe que tanto o homem quanto a mulher podem praticar livremente atos de administração necessários ao desempenho de

${ }^{10}$ MANFRÉ, José Antônio Encinas. Regime matrimonial de bens no novo código civil. São Paulo: Juarez de Oliveira, 2003. p. 13-14.

${ }^{11}$ Ibidem. 
sua função ou profissão, observando as limitações estabelecidas no inciso I do art. 1.647, bem como desobrigar ou reivindicar os imóveis que tenham sido gravados ou alienados sem o seu consentimento ou sem suprimento judicial; demandar a rescisão dos contratos de fiança e doação, ou a inovação do aval, realizados pelo outro cônjuge com infração do disposto nos incisos III e IV do artigo 1.647; reivindicar os bens comuns, móveis ou imóveis, doados ou transferidos pelo outro cônjuge ao concubino, desde que provado que os bens não foram adquiridos pelo esforço comum destes, se o casal estiver separado de fato por mais de cinco anos e, por fim, podem praticar todos os atos que não lhes forem vedados expressamente.

Neste momento é primordial dar-se plena atenção ao disposto nos artigos 1.643, 1.647 e 1.648 do Código Civil, por tratarem de matéria objeto do presente estudo.

Assim, o artigo 1.643 dispõe sobre as hipóteses que os cônjuges podem praticar atos sem autorização do outro, a saber: I- comprar, ainda a crédito, as coisas necessárias à economia doméstica; II- obter, por empréstimo, as quantias que a aquisição dessas coisas possa exigir.

Já o artigo 1.647 dispõe que, ressalvado o disposto no artigo 1.648, nenhum dos cônjuges poderá praticar atos sem a devida autorização do outro, exceto no regime da separação absoluta, nos seguintes casos: Ialienar ou gravar de ônus real os bens imóveis; pleitear, como autor ou réu, acerca desses bens ou direitos; III- prestar fiança ou aval; fazer doação não sendo remuneratória, de bens comuns, ou dos que possam integrar futura meação.

Por sua vez, o artigo 1.648 estabelece que caberá ao juiz, nos casos do artigo antecedente, suprir a outorga, quando um dos cônjuges a denegue sem motivo justo, ou lhe seja impossível concedê-la.

\section{DA INCIDÊNCIA DO ARTIGO 978 APENAS AO EMPRESÁRIO INDIVIDUAL CASADO}

A pessoa natural, a qual exerce sozinha a atividade empresarial é denominada de empresário individual, ao passo que a pessoa jurídica é denominada de sociedade empresária e, assim, é sujeito de direito. Logo, não há de se falar na possibilidade do aludido artigo abranger a sociedade empresária. 
Ocorre que, cotidianamente a pessoa jurídica empresária é denominada erroneamente de "empresa" e seus sócios são taxados como empresários, gerando assim uma grande confusão.

Em termos técnicos e jurídicos, a empresa é a atividade e não a pessoa que a explora. Quanto ao empresário esse não é o sócio da sociedade empresarial, mas sim a própria sociedade.

É extremamente importante enfatizar que o sócio, o qual integra uma sociedade empresária, não é empresário, logo, não está sujeito às normas que definem os direitos e deveres do empresário.

A distinção técnica entre empresário individual, sociedade empresária e sócio é utilizada pelo legislador no Código Civil para, principalmente, distinguir o empresário, pessoa natural, da sociedade empresária.

Nesse passo, o legislador na disposição textual do artigo 978 do Código Civil adotou a expressão empresário para se referir ao empresário individual (pessoa natural) e, desse modo, faz a distinção com relação à sociedade empresária.

Verifica-se nos artigos do Código Civil a distinção entre empresário e sociedade, como exemplo: $1.142^{12}, 1.150^{13}, 1.166^{14}, 1.179$, parágrafo único. ${ }^{15}$

12 Art. 1.142. Considera-se estabelecimento todo complexo de bens organizado, para exercício da empresa, por empresário, ou por sociedade empresária. In: BRASIL. Lei no 10.406, de 10 de janeiro de 2002. Disponível em: <http://www.planalto.gov.br/ccivil_03/LEIS/2002/L10406.htm>. Acesso em: 17. Ago. 2013.

${ }^{13}$ Art. 1.150. O empresário e a sociedade empresária vinculam-se ao Registro Público de Empresas Mercantis a cargo das Juntas Comerciais, e a sociedade simples ao Registro Civil das Pessoas Jurídicas, o qual deverá obedecer às normas fixadas para aquele registro, se a sociedade simples adotar um dos tipos de sociedade empresária. In: BRASIL. Lei no 10.406, de 10 de janeiro de 2002. Disponível em: <http://www.planalto.gov.br/ccivil_03/LEIS/2002/L10406.htm>. Acesso em: 17. Ago. 2013.

${ }^{14}$ Art. 1.166. A inscrição do empresário, ou dos atos constitutivos das pessoas jurídicas, ou as respectivas averbações, no registro próprio, asseguram o uso exclusivo do nome nos limites do respectivo Estado. In: BRASIL. Lei no 10.406, de 10 de janeiro de 2002. Disponível em: <http://www.planalto.gov.br/ccivil_03/LEIS/2002/L10406.htm>. Acesso em: 17. Ago. 2013.

${ }^{15}$ Art. 1.179. O empresário e a sociedade empresária são obrigados a seguir um sistema de contabilidade, mecanizado ou não, com base na escrituração uniforme de seus livros, em correspondência com a documentação respectiva, e a levantar anualmente o balanço patrimonial e o de resultado econômico. Parágrafo único. A adoção de fichas não dispensa o uso de livro apropriado para o lançamento do balanço patrimonial e do de resultado econômico. In: BRASIL. Lei no 10.406, de 10 de janeiro de 2002. Disponível em: <http://www.planalto.gov.br/ccivil_03/LEIS/2002/L10406.htm>. Acesso em: 17. Ago. 2013. 
Isto posto, não há que se falar na possibilidade do artigo 978 do Código Civil abranger a sociedade empresária e, tampouco, os sócios dessa, uma vez que o artigo supra refere-se apenas e tão somente ao empresário individual casado.

\subsection{ARTIGO 978 DO CÓDIGO CIVIL E SUA PERMISSÃO PARA A DISPOSIÇÃO DOS BENS IMÓVEIS PELO EMPRESÁRIO INDIVIDUAL CASADO, SEM A OUTORGA DE SEU CONSORTE}

É válido mencionar o comentário feito por Antônio Cláudio da Costa Machado ao artigo 978 do Código Civil:

No sistema do CC/1916, prevalecia disposição que o cônjuge somente poderia alienar ou gravar imóvel com a autorização conjugal. Caso fosse negada, por motivo injusto, poderia ser suprida judicialmente. Essa regra causava problemas no caso das empresas individuais, pois o patrimônio do titular se confunde com o patrimônio da pessoa jurídica. O CC/2002 inovou ao dispor que o empresário casado poderá alienar ou hipotecar os imóveis que são próprios da empresa sem a outorga de seu cônjuge. Todavia, para aportar bens imóveis da sociedade conjugal à sociedade empresária, ou mesmo simples, necessitará da expressa autorização do outro cônjuge (art. 1.647, II). ${ }^{16}$

Ocorre que, antes da consolidação do novo Código Civil e, da consequente promulgação de seu artigo 978, perdurava a severidade legal de que um cônjuge apenas e tão-somente poderia alienar ou gravar um imóvel seu, se possuísse a autorização conjugal. Em caso contrário, deveria propor uma ação judicial de suprimento de consentimento.

${ }^{16}$ MACHADO, Antônio Cláudio da Costa. Código civil interpretado. Barueri: Manole, 2015. p. 791. 
Porém, isso causava complicações no caso das empresas individuais, as quais, via de regra, o patrimônio do titular (pessoa natural) se confunde com o patrimônio empresarial.

Com o advento do novo Código Civil, o empresário casado poderá alienar ou hipotecar os imóveis que são próprios da empresa, sem necessidade da outorga de seu cônjuge. Logo, trata-se de uma clara exceção à regra da impossibilidade de alienação de bens imóveis sem a autorização do cônjuge.

Dessa forma, a disposição textual do artigo 978 do Código Civil facilita a circulação de bens empresariais permitindo assim, uma maior agilidade e racionalidade no desenvolvimento da atividade empresarial.

\subsection{A OBRIGATORIEDADE DA OUTORGA CONJUGAL PREVISTA NOS ARTS. 1.642, I E 1.647, I, DO CÓDIGO CIVIL}

O artigo 1.642 do Código Civil dispõe que: "Qualquer que seja o regime de bens, tanto o marido quanto a mulher podem livremente: I - praticar todos os atos de disposição e de administração necessários ao desempenho de sua profissão, com as limitações estabelecidas no inciso I do art. 1.647 ".

Podem ainda, sem a autorização do outro cônjuge: "II - administrar os bens próprios; III - desobrigar ou reivindicar os imóveis que tenham sido gravados ou alienados sem o seu consentimento ou sem suprimento judicial; IV - demandar a rescisão dos contratos de fiança e doação, ou a invalidação do aval, realizados pelo outro cônjuge com infração do disposto nos incisos III e IV do art. 1.647; V - reivindicar os bens comuns, móveis ou imóveis, doados ou transferidos pelo outro cônjuge ao concubino, desde que provado que os bens não foram adquiridos pelo esforço comum destes, se o casal estiver separado de fato por mais de cinco anos; VI - praticar todos os atos que não lhes forem vedados expressamente.".

Segundo Carlos Roberto Gonçalves:

O novo diploma concentra, nos dois primeiro incisos, a liberdade do marido e da mulher para a prática de todo ato de disposição e de administração de que necessitem no exercício das respectivas profissões 
(tais como as de comerciantes, profissionais liberais ou empresários, que exigem frequentemente disposição ou alienação de bens), bem como de todo ato de administração dos bens próprios, ou seja, dos que não integram a comunhão, consoante o regime de bens adotado. São ressalvados, todavia, no inciso I, os imóveis, bem como os direitos reais sobre imóveis alheios, que nem o marido nem a mulher podem dispor sem a anuência do consorte. ${ }^{17}$

O inciso III do artigo supra, tem como escopo a preservação do patrimônio do casal, pois permite a qualquer dos consortes, e não apenas à mulher, desobrigar ou reivindicar os bens imóveis que tenham sido gravados ou alienados sem o seu consentimento, ressalvada a hipótese de o ato ter sido praticado após a obtenção do suprimento judicial do consentimento.

Complementa Carlos Roberto Gonçalves que:

Segundo o inciso IV, se um dos consortes "prestar fiança ou aval" ou fizer "doação, não sendo remuneratória, de bens comuns, ou dos que possam integrar futura meação", não sendo o regime da absoluta separação (CC, art. 1.647, III e IV), poderá o outro demandar a sua anulação. Estatui o art. 1.646 do Código Civil que, "no caso dos incisos III e IV do art. 1.642 , o terceiro, prejudicado com a sentença favorável ao autor, terá direito regressivo contra o cônjuge, que realizou o negócio jurídico, ou seus herdeiros. ${ }^{18}$

Logo, para Carlos Roberto Gonçalves ${ }^{19}$ o terceiro prejudicado terá a aludida ação regressiva, portanto, nos casos de ausência de consentimento do outro cônjuge e de suprimento judicial.

Por sua vez, o inciso V do artigo 1.642, dispõe que tanto o marido quanto a mulher podem livremente reivindicar os bens comuns, móveis ou

17 GONÇALVES. Carlos Roberto. Direito civil brasileiro: direito de família. São Paulo: Saraiva, 2012. p. 432.

18 Ibidem.

${ }^{19}$ Ibidem. 
imóveis, doados ou transferidos pelo outro cônjuge ao concubino, desde que provado que os bens não foram adquiridos pelo esforço comum destes, se o casal estiver separado de fato por mais de cinco anos.

$\mathrm{O}$ inciso $\mathrm{V}$ do artigo supra ao mencionar a palavra concubino tem o intuito de impedir que haja confusão com a palavra companheiro, por inexistir união estável, mas sim, relação adulterina.

Por último, o inciso VI do aludido artigo 1.642 do Código Civil menciona que todos os atos não vedados expressamente pela lei podem ser praticados livremente por qualquer dos cônjuges.

Frente a essa disposição, Carlos Roberto Gonçalves preceitua que:

Utilizou o legislador o critério da exclusão: ressalvadas as vedações legais, tudo o mais é permitido, mesmo porque, segundo o princípio da legalidade insculpido no art. 5. ${ }^{\circ}$, II, da Constituição Federal, ninguém é obrigado a fazer ou deixar de fazer algo, senão em virtude da lei. ${ }^{20}$

A partir da explicação do artigo 1.642 e seus incisos, válida é a menção ao artigo 978 do Código Civil, o qual estabelece a possibilidade do empresário individual (pessoa natural) casado alienar ou gravar de ônus real bens imóveis que pertençam ao patrimônio da firma individual, sem a outorga do outro cônjuge.

Conforme já foi dito anteriormente, o patrimônio do empresário individual é um só, indivisível, pois ausente à distinção entre o seu patrimônio pessoal (pessoa natural) e o patrimônio empresarial.

Ocorre que, na constância do matrimônio a autonomia dos cônjuges é relativa, frente à administração de seus bens, pois há a exigência da outorga conjugal em diversas situações, principalmente no que tange ao

${ }^{20}$ GONÇALVES. Carlos Roberto. Direito civil brasileiro: direito de família. São Paulo: Saraiva, 2012. p. 432. 
patrimônio e a disposição dos bens imóveis, nos termos dos arts. 1.642, $\mathrm{I}^{21}$ e 1.647, $\mathrm{I}^{22}$, ambos do Código Civil.

Segundo o artigo 226, $\$ 5 .^{\circ}$, os direitos e deveres referentes à sociedade conjugal são exercidos igualmente pelo homem e pela mulher. Logo, entende-se que a regra é que ambos os consortes participem da administração da sociedade conjugal, de forma igualitária.

Assim, límpido é que essa disposição constitucional em consonância com os arts. 1.642, I e 1.647, I, do CC, objetivam a proteção do patrimônio familiar por ambos os consortes, os quais devem decidir sobre o patrimônio em conjunto e em igualdade de condições.

Nas palavras de Caio Mário da Silva Pereira ${ }^{23}$, se ambos os cônjuges são iguais e têm o dever de suportar os encargos da família, têm o direito de decidir (em conjunto) sobre a disposição dos bens imóveis.

Segundo Sílvio Rodrigues:

O objetivo do nosso diploma legal foi assegurar não só a harmonia e segurança da vida conjugal, mas também preservar o patrimônio familiar, forçando os consortes a manter acervo familiar, porque a renda para a manutenção da família, geralmente, advém desse, e, assim, evita-se a dissipação, garantindo, consequentemente, uma certa receita. ${ }^{24}$

Assim sendo, a outorga prevista nos arts. 1.642, I e 1.647, I, ambos do Código Civil, consiste na autorização que um cônjuge concede ao

\footnotetext{
${ }^{21}$ Art. 1.642. Qualquer que seja o regime de bens, tanto o marido quanto a mulher pode livremente:I - praticar todos os atos de disposição e de administração necessários ao desempenho de sua profissão, com as limitações estabelecidas no inciso I do art. 1.647; In: BRASIL. Lei no 10.406, de 10 de janeiro de 2002. Disponível em: <http://www.planalto.gov.br/ccivil_03/LEIS/2002/L10406.htm>. Acesso em: 17. Ago. 2013.

22 Art. 1647. Ressalvado o disposto no art. 1648, nenhum dos cônjuges pode, sem autorização do outro, exceto no regime de separação absoluta: I - alienar ou gravar de ônus real os bens imóveis; In: BRASIL. Lei no 10.406, de 10 de janeiro de 2002. Disponível em: <http://www.planalto.gov.br/ccivil_03/LEIS/2002/L10406.htm>. Acesso em: 17. Ago. 2013.

${ }^{23}$ PEREIRA, Caio Mário da Silva. Instituições de direito civil: direito de família. Rio de Janeiro: Forense, 2004. p. 199.

${ }^{24}$ RODRIGUES, Sílvio. Direito civil: direito de família. São Paulo: Saraiva, 2004. p. 186.
} 
outro para que este possa realizar atos de disposição sobre o patrimônio da família.

A autorização dada pelo marido é chamada de outorga marital e a autorização dada pela mulher é chamada de outorga uxória.

O estabelecido pelo inciso I do artigo 1.642 do Código Civil corrobora e atesta a necessidade da estabilidade e firmeza do patrimônio familiar, posto que, interligado com o inciso I do 1.647 do Código Civil, ergue-se um liame acobertado pela Constituição Federal (art. 226, §5. ${ }^{\circ}$ ).

É imprescindível mencionar o julgado do Tribunal de Justiça do Distrito Federal:

Apelação Cível - Procuração Em Causa Própria (Art. 685 Do Cc)- atributos - direitos reais - necessidade de outorga uxória - legitimidade para argui-la - negócio jurídico não eivado de vício de vontade que se perfectibiliza. i). o mandato em causa própria é verdadeiro contrato pelo qual o mandatário recebe poderes exclusivamente para adquirir certo $\mathrm{e}$ determinado bem de propriedade do mandante, sem obrigação de prestar contas, irrevogável e não sujeito às causas de extinção do mandato, nem mesmo a morte de qualquer das partes (art. 685). Aprocuratio in rem suam se equipara e vale pelo próprio contrato, desde que observadas as formalidades exigidas para 0 contrato a que se destina, "podendo ser levada a registro como se fosse o ato definitivo", segundo ensinamento de Caio Mario da Silva Pereira.ii) necessidade de anuência da esposa do outorgante ao negócio jurídico, por tratar-se de cessão de direitos sobre o imóvel, com consequente negociação da posse sobre o bem objeto da demanda, a atrair a aplicação cogente do art. 1647, i, c/c 1660, i, ambos do código civil. iii) anulabilidade que não se decreta, uma vez que arguida por quem não detém legitimidade, nos termos do art. 1650, do código civil. Ademais, a alegação da própria torpeza não encontra guarida no ordenamento jurídico. iv) o mero arrependimento, destituído da prova da ocorrência de quaisquer vícios, não autoriza a decretação da nulidade do negócio jurídico. v) negócio jurídico apto a produzir efeitos, uma vez que não restaram 
demonstrados vícios a macular-lhe a essência. Apelo Improvido. ${ }^{25}$ (Grifos Nosso)

Diante de todo o exposto, conclui-se que a exigência da outorga prevista nos arts. 1.642, I e 1.647, I do CC, tem como objetivo a proteção do patrimônio familiar e a igualdade entre os cônjuges que, por conseguinte, está sob o abrigo da Constituição Federal (artigo 226, §5. ${ }^{\circ}$ ).

\subsection{ATOS QUE UM CÔNJUGE NÃO PODE PRATICAR SEM A ANUÊNCIA DO OUTRO E O SUPRIMENTO JUDICIAL}

O artigo 1.647 do Código Civil faz menção a uma série de atos praticáveis por um dos cônjuges, para os quais se não houver autorização prévia do outro ou suprimento judicial para tanto, serão passíveis de desconstituição em juízo, "exceto no regime da separação absoluta.":

a) "Alienar ou gravar de ônus os bens imóveis;" - Segundo Antônio Cláudio da Costa Machado:

A razão para a prévia autorização de um dos cônjuges para a alienação ou gravação de ônus real de bens imóveis é explicitada no ensinamento de Clóvis Beviláqua, para o qual "os imóveis podem oferecer uma base mais segura ao bem-estar da família ou, pelo menos, lhe proporcionarão um abrigo na desventura", sendo "o lar a terra nutrix, que o Código defende de possíveis dilapidações, no interesse da família." Salienta-se que, se um dos cônjuges não puder exercer a administração dos bens imóveis, sejam comuns ou somente a eles pertencentes, a

\footnotetext{
${ }^{25}$ BRASIL. Tribunal de Justiça do Distrito Federal. APC: 20060410037185 df. relator: Carmen Bittencourt. Data de julgamento: 24/09/2008. $1^{\text {a }}$ turma cível. Data de publicação: 13/10/2008. Disponível em: <http://tj-df.jusbrasil.com.br/jurisprudencia/2453765/apelacao-civel-apc-20060410037185-df>. Acesso em: 15. Out. 2015.
} 
alienação pelo consorte deverá ser precedida de autorização judicial (art. 1.651, III, do CC). ${ }^{26}$

b) "pleitear, como autor ao réu, acerca desses bens ou direitos;" - A disposição desse inciso resulta da exigência expressa do inciso anterior, pois se tratando de bens imóveis ou direitos a ele referentes (direitos reais imobiliários), o cônjuge somente poderá ajuizar uma ação com a anuência do outro, conforme artigo 10, caput, do CPC.

Caso o cônjuge resista injustificadamente a conceder a anuência, ou esteja impossibilitado para dá-la, essa será suprida judicialmente, artigo 11, caput, do CPC.

No tocante ao suprimento judicial tem-se, conforme artigo 1.648 do Código Civil, que cabe ao juiz, nos casos do artigo antecedente (1.647), suprir a outorga, quando um dos cônjuges a denegue sem motivo justo, ou lhe seja impossível concedê-la.

Conforme leciona Antônio Cláudio da Costa Machado:

O cônjuge que se vê impossibilitado de realizar um dos atos previsto no art. 1.647 do CC (ressalvado o caso da separação absoluta de bens) por falta de concordância do consorte pode se socorrer do Poder Judiciário para obter suprimento desse consentimento. Tal ocorre em duas hipóteses distintas: a de recusa injustificada da anuência e a da impossibilidade de sua concessão. Na primeira hipótese, o magistrado deve analisar detidamente as causas de denegação pelo cônjuge para avaliar a justificativa por ele dada para o não consentimento. Por exemplo, se o consorte se recusar à outorga por haver rusgas com o cônjuge, haverá a configuração do motivo injusto. Por outro lado, se essa recusa ocorrer porque o consorte é dotado de prodigalidade, o magistrado não suprirá a concordância. $\mathrm{Na}$ segunda hipótese, o cônjuge se vê impossibilitado de receber a outorga por motivos alheios à vontade do casal (por exemplo, doença mental incapacitante, desaparecimento do consorte, etc.). Nesse caso,

${ }^{26}$ MACHADO, Antônio Cláudio da Costa. Código civil interpretado. Barueri: Manole, 2015. p. 1.432. 
demonstrada a impossibilidade, haverá o suprimento judicial. ${ }^{27}$

c) "Prestar fiança ou aval;" - Leciona Carlos Roberto Gonçalves:

Procura-se evitar, com essa limitação, o comprometimento dos bens do casal, em razão de graciosa garantia concedida a débito de terceiro. Se a fiança e o aval não forem anulados pelo cônjuge prejudicado (o que os prestou não tem legitimidade para pedir a anulação), poderá este opor embargos de terceiro para excluir a sua meação de eventual penhora que venha a recair sobre os bens do casal, pois somente as dívidas contraídas para os fins do artigo 1.643 do Código Civil (para comprar coisas necessárias á economia doméstica e para obter, por empréstimo, as quantias que a aquisição dessas coisas possa exigir) obrigam solidariamente ambos os cônjuges. ${ }^{28}$

d) "Fazer doação, não sendo remuneratória, de bens comuns, ou dos que possam integrar futura meação." - Assim, é vedado ao cônjuge, o qual não possui consentimento do outro cônjuge ou suprimento judicial, realizar a doação (não sendo remuneratória) de bens comuns.

Segundo Carlos Roberto Gonçalves:

É permitida somente a doação remuneratória, qualquer que seja o seu valor, porque representa o pagamento de serviço prestado pelo donatário (médico, dentista, advogado, etc.), cuja cobrança não mais podia ser feita (em razão da prescrição da ação, p. ex.). A obrigação de pagar, embora nesse caso seja

${ }^{27}$ MACHADO, Antônio Cláudio da Costa. Código civil interpretado. Barueri: Manole, 2015. p. 1.434 .

${ }^{28}$ GONÇALVES, Carlos Roberto. Direito civil brasileiro. São Paulo: Saraiva, 2010. p. 438. 
apenas moral, existe e o pagamento pode ser feito sem a anuência do outro cônjuge. ${ }^{29}$

Salienta-se ainda que, quanto à proibição contida nesse inciso, essa se aplica somente aos bens móveis, uma vez que dos imóveis já trata o inciso I.

\subsection{O EMPRESÁRIO INDIVIDUAL E A INTERFERÊNCIA DO REGIME MATRIMONIAL DE BENS NA ATIVIDADE EMPRESARIAL}

No que tange ao artigo $978^{30}$ do Código Civil, esse concedeu amplos poderes ao empresário individual casado para dispor sobre bens imóveis que pertençam ao patrimônio da empresa sem a outorga de seu consorte, independentemente do regime de bens.

É importante reiterar que o empresário individual exerce a atividade empresarial mediante firma individual e, a esse não é concedido personalidade jurídica distinta da pessoa natural, por consequência, o patrimônio da pessoa natural se confunde com o patrimônio da empresa, ou seja, torna-se uma única unidade.

Logo, não há que se falar no patrimônio da empresa, a princípio, porque o patrimônio é uno e diz respeito à pessoa natural, sujeito de direitos e deveres.

Assim, conforme julgados:

RECURSO - REPRESENTAÇÃO - ELEIÇÕES 2012 - PRESTAÇÃO DE SERVIÇOS CONTÁBEIS REALIZADO POR EMPRESÁRIO INDIVIDUAL PEDIDO DE CONDENAÇÃO POR SUPOSTA DOAÇÃO DE CAMPANHA ESTIMÁVEL EM

${ }^{29}$ GONÇALVES, Carlos Roberto. Direito civil brasileiro. São Paulo: Saraiva, 2010. p. 438.

30 "O empresário casado pode, sem necessidade outorga conjugal, qualquer que seja o regime de bens, alienar os imóveis que integrem o patrimônio da empresa ou gravá-los de ônus real." In: BRASIL. Lei no 10.406, de 10 de janeiro de 2002. Disponível em: <http://www.planalto.gov.br/ccivil_03/LEIS/2002/L10406.htm>. Acesso em: 17. Ago. 2013. 
DINHEIRO ACIMA DO LIMITE LEGAL FIXADO PARA AS PESSOAS JURÍDICA (LEI N. 9.504/1997, ART. 81, § 1. ${ }^{\circ}$, I)- ATIVIDADE EMPRESARIAL INCAPAZ DE CRIAR PERSONALIDADE JURÍDICA DISTINTA DO TITULAR DA FIRMA INDIVIDUAL EQUIPARAÇÃO À PESSOA FÍSICA EM RAZÃO DA EVIDENTE CONFUSÃO PATRIMONIAL OBSERVÂNCIA DO DISCIPLINAMENTO LEGAL PREVISTO PARA A DOAÇÃO ESTIMADA DE PESSOA FÍSICA, INCLUINDO A EXCLUDENTE DO $\S 7 .^{\circ}$ DO ART. 23 DA LEI N. 9.504/1997 - PROVIMENTO.

1. De acordo com o Superior Tribunal de Justiça, "empresário individual é a própria pessoa física ou natural, respondendo os seus bens pelas obrigações que assumiu, quer civis quer comerciais" (REsp 594832, DJ de 01.08.2005, Min. Nancy Andrighi), razão pela qual devem ser juridicamente equiparados. Logo, o serviço contábil gratuitamente prestado a candidato por determinada firma individual constitui doação estimável em dinheiro sujeita ao disciplinamento legal previsto para a contribuição da pessoa física, estando, portanto, abrangida pela excludente estabelecida pelo $\S 7 .^{\circ}$ do art. 23 da Lei n. $9.504 / 1997 .{ }^{31}$ (Grifos nosso)

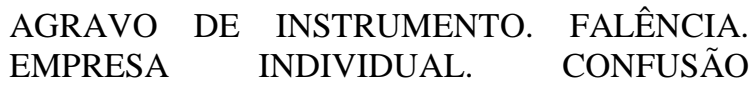
PATRIMONIAL. ATIVIDADE EMPRESARIAL E INDIVIDUAL. PATRIMÔNIO ÚNICO. ARRECADAÇÃO DA TOTALIDADE DOS BENS DO EMPRESÁRIO INDIVIDUAL, ESTEJAM VINCULADOS A ATIVIDADE EMPRESARIAL OU NÃO. POSSIBILIDADE JURÍDICA.

1. Em se tratando de falência o patrimônio do empresário individual confunde-se com o pessoal, de

${ }^{31}$ BRASIL. Tribunal Regional Eleitoral - Santa Catarina. RDJE: 15020 SC. Relator: Sérgio Roberto Baasch Luz. Data de Julgamento: 12/03/2014. Data de Publicação: DJE Diário de JE. Tomo 40. Data 19/03/2014. Disponível em: < http://tre-sc.jusbrasil.com.br/jurisprudencia/1 16662634/recurso-contra-decisoes-de-juizes-eleitorais-rdje-15020-sc/inteiro-teor-116662646>. Acesso em: 17. Ago. 2015. 
sorte que corresponde a um só conjunto de bens, mesmo que sirva à atividade empresarial exercida de forma individual. Portanto, em havendo confusão patrimonial entre os bens destinados a atividade empresarial e aqueles individualmente utilizados, o patrimônio é único, logo, é perfeitamente possível à realização da arrecadação em relação aos bens do empresário individual.

2. Por conseguinte, com a declaração de falência, o empresário individual é desapossado de todos os seus bens e direitos, os quais, a partir da publicação da sentença, devem ser objeto de arrecadação para a formação da massa objetiva.

3. Dessa forma, manter a decisão agravada que determinou a arrecadação dos bens do empresário individual para compor a massa objetiva, é a medida que se impõe Negado provimento ao agravo de instrumento. ${ }^{32}$ (Grifos nosso)

AGRAVO DE INSTRUMENTO. AÇÃO DE RESCISÃO DE CONTRATO LOCATÍCIO. FASE DE CUMPRIMENTO DE SENTENÇA. COBRANÇA DE HONORÁRIOS DE ADVOGADO. EMPRESA INDIVIDUAL. CONFUSÃO PATRIMONIAL COM OS BENS DO TITULAR. DESNECESSÁRIA A DESCONSIDERAÇÃO DA PERSONALIDADE JURÍDICA. POSSIBILIDADE DE PENHORA “ON LINE" SOBRE AS CONTAS BANCÁRIAS DA EXECUTADA. REFORMA DA DECISÃO. 1. Cuida-se de ação de rescisão de contrato locatício, em fase de cumprimento de sentença, na qual o ora agravante pretende a cobrança dos honorários de advogado no valor de $\mathrm{R} \$ 5.547,27$, em virtude de ter patrocinado os interesses do réu. 2. Sabe-se que a firma individual não possui personalidade jurídica própria e independente de seu titular, não havendo

${ }^{32}$ BRASIL. Tribunal de Justiça do Rio Grande do Sul. Agravo de Instrumento N. ${ }^{\circ}$ 70061018792. Quinta Câmara Cível. Relator: Jorge Luiz Lopes do Canto. Julgado em 10/12/2014. Disponível em: <http://tj-rs.jusbrasil.com.br/ jurisprudencia/158296145/agravo-de-instrumento-ai-70061018792-rs/inteiro-teor-158296163>.

Acesso em: 15. Out. 2015. 
distinção entre ela e a pessoa física do comerciante/empresário, portanto o patrimônio deste responde por todas as obrigações assumidas pela empresa, sendo denominada pela jurisprudência como confusão patrimonial. 3. Desnecessária a desconsideração da personalidade jurídica da ora agravada para fins de penhora dos bens particulares de seu titular. 4. Precedentes jurisprudenciais do STJ e desta E. Corte de Justiça. 5. Deferimento da penhora online nas contas bancárias do titular da empresa devedora. 6. Recurso provido. ${ }^{33}$ (Grifos nosso).

Porém, da leitura do artigo 978 do CC, chega-se à conclusão que está se admitindo, de forma equivocada, a existência do patrimônio da empresa separado do patrimônio pessoal e, assim, poderia o empresário alienar os bens imóveis pertencentes a esse patrimônio, ou gravá-los de ônus real, sem necessidade de outorga conjugal.

Com a entrada em vigor do artigo 978 supra, com o Código Civil de 2.002, esse trouxe uma disposição, a qual não condiz com a realidade do regime jurídico do empresário individual, gerando, assim, diversas dúvidas frente a sua aplicação na prática.

A principal dúvida é: Teria o legislador permitido que o empresário disponha dos bens imóveis pertencentes ao patrimônio da pessoa natural casada, destinada à atividade empresarial, sem a anuência do outro cônjuge?

Leciona Mônica Gusmão ${ }^{34}$ que no tocante a situação prevista no art. 978 a meação do cônjuge não empresário deve ser preservada, pois a intenção da regra é facilitar o exercício e a preservação da empresa sem desguarnecer o cônjuge empresário.

Nesse diapasão, segundo Ricardo Fiuza:

${ }^{33}$ BRASIL. Tribunal de Justiça do Estado do Rio de Janeiro. Agravo de instrumento n. ${ }^{\circ}$ 0058638-70.2013.8.19.0000. Oitava Câmara Cível. Relatora: Des. Mônica Maria Costa. Disponível em: <http://tj-rj.jusbrasil.com.br/jurisprudencia/116621793/agravo-de-instrumento-ai-586387020138190000-rj-0058638-7020138190000/inteiro-teor-143726406>.

Acesso em: 15. Out. 2015.

${ }^{34}$ GUSMÃO, Mônica. Curso de Direito Empresarial. 5. ed. Rio de Janeiro: Lumen Juris, 2007. p. 285. 
No que se refere às firmas individuais, que não adquirem personalidade jurídica própria, a norma em referência estabelece que, relativamente ao patrimônio imobiliário destinado pelo empresário para o exercício de sua atividade, tais bens poderão ser alienados ou gravados de ônus reais sem a necessidade de consentimento do respectivo cônjuge, uma vez que os bens imóveis diretamente afetados à atividade da empresa não estão compreendidos no patrimônio conjugal. ${ }^{35}$

Assim, somente os bens, os quais são pertencentes à atividade empresarial serão alvo do artigo 978 do Código Civil e da sua consequente liberdade concedida ao cônjuge casado.

Entretanto, nos casos dos Regimes de Bens, exceto no da separação absoluta, a meação do outro cônjuge fica ameaçada, pois a princípio o patrimônio do empresário casado é uno e, portanto, confunde-se com o patrimônio pessoal da pessoa natural, sujeito de direitos, conforme julgados supra.

Nesse passo, com o intuito de preservar o patrimônio familiar, o artigo 1.647 do Código Civil estipula em seus incisos as hipóteses em que será expressamente necessária a anuência do outro cônjuge.

A autorização expressa para a prática de alguns atos é uma forma, a qual o legislador encontrou para fazer com que ambos os cônjuges participem das decisões inerentes à administração do patrimônio familiar e, como forma de evitar a dissipação desse patrimônio por um do casal.

Reitera-se que a anuência de um cônjuge para que o outro possa alienar ou gravar de ônus real bens imóveis, é indispensável para que haja a estabilidade e manutenção do patrimônio familiar.

Conclui-se, pois, que o artigo 978 do Código Civil afronta a regra geral, a qual estabelece a necessidade de outorga marital ou uxória.

Conforme Marilene Silveira Guimarães:

A autonomia para o cônjuge empresário alienar patrimônio imóvel sem consentimento do outro afronta a regra geral que estabelece a necessidade de

${ }^{35}$ FIÚZA, Ricardo. Novo código civil comentado. São Paulo: Saraiva, 2009. p. 884. 
outorga uxória ou marital, visando proteger o cônjuge e, por consequência, a família, principalmente quando todo o patrimônio do casal como - a residência, os automóveis, os telefones, a casa de veraneio - forem adquiridos em nome da empresa e a sua alienação causará prejuízo à meação. ${ }^{36}$

Desse modo, é interessante mencionar que o empresário pode não obter sucesso na sua atividade empresarial, até mesmo porque ninguém está salvo de insucessos e, assim, contrair obrigações, como empréstimo, financiamento, por exemplo, e posteriormente não conseguir solvê-las.

Com o não cumprimento dessas obrigações o patrimônio familiar pode ser afetado e, dessa forma prejudicar o outro cônjuge, pois como já foi dito o patrimônio do empresário é uno.

Desse modo, instituiu o legislador o bem de família obrigatório, por meio da Lei 8.009/90.

Conforme artigo $1 .^{\circ}$ da Lei supra:

Art. 1. - - O imóvel residencial próprio do casal, ou da entidade familiar, é impenhorável e não responderá por qualquer tipo de dívida civil, comercial, fiscal, previdenciária ou de qualquer outra natureza, contraída pelos cônjuges ou pelos pais ou filhos que sejam seus proprietários e nele residam salvo nas hipóteses previstas nesta Lei.

O artigo 5. ${ }^{\circ}$ da referida Lei complementa que: "Art. 5. - Para os efeitos de impenhorabilidade, de que trata esta lei, considera-se residência um único imóvel utilizado pelo casal ou pela entidade familiar para moradia permanente".

Assim, conclui-se que como a responsabilidade do empresário individual é ilimitada, como já foi anteriormente explanado, é concedida a proteção legal ao bem de família utilizado para moradia permanente, uma

\footnotetext{
${ }^{36}$ GUIMARÃES, Marilene Silveira. Família e empresa: questões controvertidas (regime de bens e os reflexos dos arts. 977, 978 e 979 no direito de família). In: PEREIRA, Rodrigo da Cunha (coord.). Afeto, ética, família e o novo código civil. Belo Horizonte: Del Rey, 2004. p. 449.
} 
vez que seu patrimônio é uno, respondendo, consequentemente, por todas as obrigações contraídas.

A exceção à regra de impenhorabilidade está contida no artigo 3. ${ }^{\text {o37 }}$ da Lei 8.009/99 e constitui rol taxativo.

O artigo 978 do Código Civil constitui uma exceção ao artigo 1.647, I do CC e, gera uma instabilidade e insegurança na sua aplicação em casos práticos, em razão de eventuais atos lesivos ao cônjuge não empresário e à família.

Assim sendo, apesar da intenção do artigo 978 do CC de estimular a atividade empresarial, esse peca ao atribuir ao empresário individual uma característica inusitada, a qual não possui amparo legal para ser colocada em prática.

Nesse diapasão, frente à instabilidade causada pela aplicação do artigo 978 do CC na prática, apresenta-se a seguir duas soluções na tentativa de solucionar a contradição entre o direito empresarial e o direito de família.

A primeira diz respeito à possibilidade do entendimento jurisprudencial acolher o artigo 978 do CC como exceção ao artigo 1.647, I do CC, permitindo assim que o empresário disponha livremente dos bens imóveis pertencentes à empresa sem a anuência do outro cônjuge.

Caso esse entendimento seja acolhido pelos Tribunais, deverá o empresário individual de imediato com a autorização do outro cônjuge, registrar a "afetação" do bem em sua respectiva matrícula. Permitindo dessa forma, a publicidade registral e, consequentemente, a possibilidade de dispor do bem imóvel na sua atividade empresarial, caso que, a anuência do

\footnotetext{
${ }^{37}$ Art. $3^{\circ} \mathrm{A}$ impenhorabilidade é oponível em qualquer processo de execução civil, fiscal, previdenciária, trabalhista ou de outra natureza, salvo se movido:I-em razão-dos-réditos de trabalhadores da própria residência das respectivas contribuições previdenciárias; II pelo titular do crédito decorrente do financiamento destinado à construção ou à aquisição do imóvel, no limite dos créditos e acréscimos constituídos em função do respectivo contrato; HI - pelo credor de pensão alimentícia; III - pelo credor da pensão alimentícia, resguardados os direitos, sobre o bem, do seu coproprietário que, com o devedor, integre união estável ou conjugal, observadas as hipóteses em que ambos responderão pela dívida;IV para cobrança de impostos, predial ou territorial, taxas e contribuições devidas em função do imóvel familiar; V - para execução de hipoteca sobre o imóvel oferecido como garantia real pelo casal ou pela entidade familiar; VI - por ter sido adquirido com produto de crime ou para execução de sentença penal condenatória a ressarcimento, indenização ou perdimento de bens; VII - por obrigação decorrente de fiança concedida em contrato de locação.
} 
outro cônjuge já foi concedida e registrada a margem da respectiva matrícula.

Essa possibilidade configura uma solução, a qual garante o mínimo de segurança ao cônjuge não empresário e a terceiros que venham contratar com o empresário, já que a anuência conjugal já estará averbada a margem da respectiva matrícula do bem imóvel envolto na atividade empresarial.

Uma segunda solução à insegurança, a qual é gerada pela aplicação do artigo 978 do CC é a EIRELI (Empresa Individual de Responsabilidade Limitada), cuja sociedade é unipessoal, ou seja, é formada por apenas uma única pessoa, a qual detém o controle do negócio.

A EIRELI foi instituída através da Lei n. ${ }^{\circ} 12.441 / 11$, e permite que uma única pessoa natural possa, sem precisar formar sociedade com nenhuma outra pessoa, constituir uma pessoa jurídica com responsabilidade limitada ao capital integralizado.

Sem dúvidas, a EIRELI representa um grande avanço, pois diferentemente do empresário individual, essa possui responsabilidade limitada ao capital integralizado, ao passo que aquele possui uma responsabilidade ilimitada e a responsabilidade pelas dívidas contraídas recaem sobre o patrimônio natural e empresarial do empresário.

Assim, a Lei 12.441/11 representa um grande avanço legislativo, pois essa prevê a total separação entre o patrimônio da pessoa jurídica e o da pessoa física, ao passo que, quanto ao empresário individual essa disposição não se aplica e, em caso de insucesso o patrimônio desse, o qual é uno (patrimônio empresarial + patrimônio pessoal), arcará com os prejuízos, exceto os bens exclusivamente impenhoráveis.

Por todo o exposto, conclui-se, que a aplicação do artigo 978 na prática gera uma insegurança, visto que se encontra em contradição com o artigo 1.647, I, do CC, gerando conflitos com o direito de família, devido à dificuldade de sua aplicação de imediato, haja vista a possibilidade de se prejudicar o outro cônjuge meeiro.

Corrobora-se que, por mais que a intenção do legislador tenha sido boa, no tocante a desenvolver e estimular a atividade empresarial, essa foi falha, pois não garante uma aplicação segura do artigo 978 do Código Civil na prática, gerando, assim, uma insegurança jurídica. 


\subsection{A PROTEÇÃO DO PATRIMÔNIO FAMILIAR E A POSIÇÃO DOS TRIBUNAIS}

Face à proteção do patrimônio familiar, Carlos Roberto Gonçalves leciona que:

A Lei n. 8.009, de 29 de março de 1990, veio ampliar o conceito de bem de família, que não depende mais de instituição voluntária, mediante as formalidades previstas no Código Civil. Agora, como foi dito, resulta ele diretamente da lei, de ordem pública, que tornou impenhorável o imóvel residencial, próprio do casal, ou da entidade familiar, que não responderá por qualquer tipo de dívida civil, comercial, fiscal, previdenciária ou de outra natureza, contraída pelos cônjuges ou pelos pais ou filhos que sejam seus proprietários e nele residam, salvo nas hipóteses expressamente previstas nos arts. $2 .^{\circ}$ e $3 .^{\circ}$, I a VII (fiança em contrato de locação, pensão alimentícia, impostos e taxas que recaem sobre o imóvel etc.). ${ }^{38}$

Álvaro Villaça Azevedo, complementa ainda que "o bem de família é um meio de garantir um asilo à família, tornando-se o imóvel onde ela se instala domicílio impenhorável e inalienável, enquanto forem vivos os cônjuges e até que os filhos completem sua maioridade." ${ }^{39}$

Assim sendo, diante do exposto no decorrer do presente artigo, tem-se que o consentimento de um cônjuge para que o outro possa alienar ou gravar de ônus real bens imóveis é indispensável para a estabilidade e manutenção do patrimônio familiar.

Esse consentimento expresso é um dos meios encontrados pelo legislador para fazer com que ambos os cônjuges participem juntos sobre a administração dos bens imóveis familiares, e claro, como forma de evitar a dissipação do patrimônio por um do casal.

${ }^{38}$ GONÇALVES, Carlos Roberto. Direito civil brasileiro: direito de família. São Paulo: Saraiva, 2012. p. 589.

${ }^{39}$ AZEVEDO, Álvaro Villaça. Bem de família. 3. ed. São Paulo: RT, 1996. p. 56. 
Nesse diapasão, o legislador com o intuito de assegurar um lar à família, valeu-se da Lei 8.009/90, a qual institui o bem de família obrigatório e, nessa qualidade, impenhorável.

$\mathrm{O}$ artigo $1^{\circ}$ da lei supramencionada dispõe que:

Art. $1^{\circ}$. O imóvel residencial próprio do casal, ou da entidade familiar, é impenhorável e não responderá por qualquer tipo de dívida civil, comercial, fiscal, previdenciária ou de qualquer outra natureza, contraída pelos cônjuges ou pelos pais ou filhos que sejam seus proprietários e nele residam salvo nas hipóteses previstas nesta Lei.

No que tange ao empresário individual, tem-se que esse possui uma responsabilidade ilimitada, entretanto lhe é concedido proteção legal do bem de família, haja vista que seu patrimônio é um só, respondendo por todas as obrigações contraídas, independentemente da natureza.

Desse modo, interessante é a menção ao acórdão advindo do Agravo de Instrumento no 2117566-14.2015.8.26.0000, o qual dispõe:

EMENTA

AGRAVO DE INSTRUMENTO - ALEGAÇÃO DE BEM DE FAMÍLIA - PROVA DE QUE O AGRAVANTE RESIDIA NO IMÓVEL PENHORADO - Em face das provas trazidas ao presente, que demonstram a verossimilhança do alegado, ou seja, de que o agravante residia no imóvel penhorado, acerca das quais, inclusive, não houve qualquer impugnação, reconhece-se a impenhorabilidade do imóvel. RECURSO PROVIDO.

"Por meio deste recurso, pretende o agravante ver reformada a decisão, que rejeitou a alegação de impenhorabilidade do bem, uma vez que o resultado da constatação realizada apontava que o imóvel não era utilizado como residência do executado.

Em que pese o entendimento esposado pelo Douto Magistrado de Primeira Instância, impõe-se a reforma da decisão agravada. 
Como se sabe, responde o devedor, para o cumprimento das suas obrigações, com todos os seus bens presentes e futuros, salvo as restrições previstas em lei (CPC, art. 591). (Grifos nosso)

Não se sujeitam à execução, contudo, os bens que a lei declara impenhoráveis ou inalienáveis $(\mathrm{CPC}$, art. 648).(Grifos nosso)

São absolutamente impenhoráveis os bens que constam do elenco do art. 649 do Código de Processo Civil, sendo relativamente impenhoráveis, na falta de outros bens, os frutos e os rendimentos de bens inalienáveis, exceto se destinados à satisfação de prestação alimentícia (art. 650). (Grifos nosso)

No caso em apreço, em que pese o oficial de justiça tenha encontrado o imóvel fechado nas diligências realizadas e constatado através de informações colhidas no local, por meio de vizinhos, que lá residia Fernanda e sua família (vide certidão de fls. 12), verossímil se mostra a alegação do recorrente no sentido de que também residia no local, ao argumento de lá residir com sua filha Fernanda e demais parentes.

Isto porque, das peças colacionadas ao presente, verifica-se que a filha do agravante de fato se chama Fernanda (vide fls. 63), existindo, ainda, diversas contas de consumo que se encontram em nome de sua esposa (telefonia e energia elétrica), modo a comprovar a condição alegada (vide fls. 67/115).

Oportuno ressaltar neste particular, que a última conta de consumo apresentada pelo agravante data de agosto de 2015, a respeito da qual não houve qualquer insurgência do agravado, apesar de ter sido instado a se manifestar no presente (vide certidão de fls. 119). Daí porque, em face das provas trazidas a este recurso, que demonstram a verossimilhança do alegado, ou seja, de que o agravante residia no imóvel penhorado, acerca das quais, inclusive, não houve qualquer impugnação, reconhece-se a impenhorabilidade do imóvel.

Desta forma, DÁ-SE PROVIMENTO ao recurso, para o fim de reconhecer a impenhorabilidade do bem de família. (Grifos nosso)" 
(Tribunal de Justiça do Estado de São Paulo - Agravo de Instrumento $\mathrm{n}^{\mathrm{o}}$ 2117566-14.2015.8.26.0000, Relator(a): Des. Maria Lúcia Pizzotti, Comarca: Santo André, Órgão julgador: $30^{\mathrm{a}}$ Câmara de Direito Privado, Data do julgamento: 21/10/2015).

A exceção à impenhorabilidade do bem de família é trazida pelo artigo $3^{\circ}$ da Lei $n^{\circ} 8.009 / 90$, a qual dispõe:

Art. $3^{\circ} \mathrm{A}$ impenhorabilidade é oponível em qualquer processo de execução civil, fiscal, previdenciária, trabalhista ou de outra natureza, salvo se movido:

I - Em razão dos créditos de trabalhadores da própria residência e das respectivas contribuições previdenciárias;

II - Pelo titular do crédito decorrente do financiamento destinado à construção ou à aquisição do imóvel, no limite dos créditos e acréscimos constituídos em função do respectivo contrato;

III - Pelo credor de pensão alimentícia;

IV - Para cobrança de impostos, predial ou territorial, taxas e contribuições devidas em função do imóvel familiar;

V - Para execução de hipoteca sobre o imóvel oferecido como garantia real pelo casal ou pela entidade familiar;

VI - Por ter sido adquirido com produto de crime ou para execução de sentença penal condenatória a ressarcimento, indenização ou perdimento de bens; VII -Por obrigação decorrente de fiança concedida em contrato de locação.

Nos tribunais superiores é pacífico o entendimento de que o artigo $3^{\circ}$, supramencionado, deve ser interpretado restritivamente, visto que a impenhorabilidade do bem de família deve ser a regra, sendo a penhora exceção.

A proteção advinda dos dispositivos legais, no tocante ao bem familiar, tem como objetivo não só resguardar a moradia da família frente às dívidas contraídas pelo empresário individual e, possível execução pelos credores, como também possibilitar o desenvolvimento da célula familiar. 
A Súmula 364 do Superior Tribunal de Justiça aduz que é necessário que se faça uma interpretação extensiva do conceito de bem de família, protegendo assim não só os imóveis habitados por famílias, como também aqueles habitados por pessoa solteira, viúva ou separada.

Essa impenhorabilidade do bem de família se faz imprescindível para lograr o êxito do princípio da dignidade da pessoa humana, no que tange ao direito à moradia, visando proteger não só o devedor, ora executado, como também toda a sua família.

Portanto, a exceção à impenhorabilidade do bem de família afasta a possibilidade de má-fé do devedor, ora executado, o qual poderia valer-se de uma impenhorabilidade absoluta e irrestrita para se beneficiar em detrimento dos interesses do credor, ora Exequente e, assim prejudicálo no possível recebimento do crédito pretendido.

\section{CONSIDERAÇÕES FINAIS}

Com a promulgação do novo Código Civil houve a tão aguardada unificação formal (legislativa) do direito privado brasileiro, consolidando assim, o Direito Comercial como o Direito de Empresa, sendo esse mais adequado para disciplinar o desenvolvimento das atividades econômicas do país.

O Código Civil promulgado em 10 de janeiro de 2.002 trouxe relevantes modificações no ordenamento jurídico brasileiro, especialmente em seu livro II- Direito de Empresa, pois fixou nova diretriz ao Direito Mercantil Brasileiro, com bases filosóficas consubstanciadas na Teoria da Empresa.

O novo Código Civil modifica tanto as relações conjugais quanto as relações empresariais, assim dentro desse contexto tem-se a regra específica do artigo 1.647, o qual proíbe a alienação de bens do cônjuge casado sem a devida autorização do outro, porém essa regra não pode ser aplicada ao empresário, pois, o artigo 978 do Código Civil, prevê a dispensa da outorga conjugal para a alienação ou oneração de bens imóveis destinados à atividade empresarial, qualquer que seja o regime de bens, para o empresário individual casado.

Logo, seria o art. 978 do CC uma exceção ao art. 1.647, I do mesmo diploma legal impedindo o cônjuge não empresário de decidir sobre o destino do bem imóvel, patrimônio da família? 
Pode-se aceitar a dispensa da outorga na situação prevista do art. 978 do CC quando a meação do cônjuge não empresário pode vir a ser constrangida por uma dívida do empresário?

Esses eram os questionamentos feitos no início da pesquisa, os quais eram frutos das indagações feitas perante a vigência do artigo 978 do Código Civil, o qual contrariava expressamente a disposição do artigo 1.647, I, do Código Civil.

Ocorre que, o legislador, ao lançar mão do artigo 978 do CC teve o intuito de estimular a atividade empresarial, porém, a aplicação desse artigo na prática gera uma insegurança, visto que se encontra em contradição com o artigo 1.647, I, do CC, gerando conflitos com o direito de família, devido à dificuldade de sua aplicação de imediato, haja vista a possibilidade de se prejudicar o outro cônjuge meeiro.

Nesse passo, como o empresário individual, bem como qualquer pessoa, não está salvo de insucessos, é interessante dispor que o empresário pode contrair certas obrigações e posteriormente não conseguir solvê-las.

Com o não cumprimento dessas obrigações o patrimônio familiar pode ser afetado e, dessa forma prejudicar o outro cônjuge, pois como já foi dito o patrimônio do empresário é uno.

Desse modo, instituiu o legislador o bem de família obrigatório, por meio da Lei 8.009/90, a qual instituiu a impenhorabilidade ao único imóvel utilizado pelo casal como moradia permanente.

A Lei 8.009/90 representa uma tentativa do legislador de evitar que com a aplicação do artigo 978 do CC na prática, esse venha prejudicar o outro cônjuge meeiro, bem como seus filhos.

Assim, na tentativa de se evitar a perda do único bem utilizado pelo casal como residência, instituiu o legislador a impenhorabilidade ao mesmo.

Como exposto, o artigo 978 do CC traz uma realidade jurídica completamente distorcida da realidade do empresário individual, pois o patrimônio pessoal desse se confunde com o patrimônio empresarial.

Assim, conclui-se que, há duas soluções para evitar possíveis problemas advindos da aplicação desse artigo completamente distorcido da realidade, o qual contraria normas do direito de família.

A primeira, como já dito, diz respeito à possibilidade do entendimento jurisprudencial acolher de forma expressa e unânime o artigo 978 do CC como exceção ao artigo 1.647, I do CC, permitindo, assim, que o 
empresário disponha livremente dos bens imóveis pertencentes à empresa sem a anuência do outro cônjuge.

Caso esse entendimento seja definitivamente e homogeneamente acolhido por todos os Tribunais, o ideal é que o empresário junto com a autorização de seu cônjuge registre imediatamente a "afetação" do bem na sua respectiva matrícula.

Objetiva-se com isso proteger o patrimônio familiar, bem como os terceiros de boa-fé, já que a anuência conjugal já estará averbada a margem da respectiva matrícula do bem imóvel envolto na atividade empresarial.

A segunda solução seria o desuso da instituição do empresário individual e, o consequente uso da EIRELI (Empresa Individual de Responsabilidade Limitada), cuja sociedade é unipessoal, ou seja, é formada por apenas uma única pessoa, a qual detém o controle do negócio.

A EIRELI representa um grande avanço, pois diferentemente do empresário individual, essa possui responsabilidade limitada ao capital integralizado, ao passo que aquele possui uma responsabilidade ilimitada e a responsabilidade pelas dívidas contraídas recai sobre o patrimônio pessoal (pessoa física) e o patrimônio do empresário (empresarial).

Diante de todo o exposto, bem como frente às soluções apresentadas, tem-se que por mais que a intenção do legislador tenha sido estimular a atividade empresarial, esse, de forma equivocada, lançou mão de um dispositivo, o qual está distorcido e contrário à realidade jurídica do empresário individual.

Quanto mais houver a aplicação do artigo 978 do CC na prática, maiores serão as possibilidades de se prejudicar o outro cônjuge meeiro, assim no intuito de se barrar essa alternativa o presente estudo lançou mão de duas possibilidades eficazes frente à vigência do artigo supra.

As soluções apresentadas objetivam contribuir com o acervo jurídico já existente, bem como auxiliar na abertura de portas para que haja cada vez mais o desbravamento dessa problemática tão polêmica, a qual envolve o conflito existente entre o artigo 978 e 1.647, I, ambos do Código Civil.

\section{REFERÊNCIAS BIBLIOGRÁFICAS}


ALMEIDA, Carolina Miguez. O empresário individual e a dispensa da outorga conjugal prevista no art. 978 do novo código civil. 2007. 67 fls. Trabalho de Conclusão de Curso. Bacharel em Ciências Jurídicas e Sociais pela Faculdade de Direito da Pontifícia Universidade Católica do Rio Grande do Sul.

ANAN JUNIOR, Pedro; PEIXOTO, Marcelo Magalhães. Empresa individual de responsabilidade limitada - EIRELI: aspectos econômicos e legais. Disponível em: <http://www.seteco.com.br/down/hm13450b6044a2177145959463

9_iniciais_eireli_site.pdf $>$. Acesso em: 27. Ago. 2015.

AZEVEDO, Álvaro Villaça. Bem de família. 3. ed. São Paulo: RT, 1996. BARROSO, Luís Roberto. Interpretação e aplicação da constituição. 6. ed. São Paulo: Saraiva, 2006.

BRUSCATO, Wilges Ariana. Empresário individual de responsabilidade limitada. São Paulo: QuartierLatin, 2005.

BRASIL. Lei no 10.406, de 10 de janeiro de 2002. Disponível em: <http://www.planalto.gov.br/ccivil_03/LEIS/2002/L10406.htm>. Acesso em: 17. Ago. 2013.

. Decreto $n^{0}$ 1.102, de 21 de novembro de 1903. Disponível em: < http://www.planalto.gov.br/ccivil_03/decreto/Historicos/DPL/DPL 1102.htm\#art36>. Acesso em: 07. Ago. 2015.

BULLENTINI, Rebeca. O direito empresarial através dos tempos. Disponível em: <http://bullentini.jusbrasil.com.br/artigos/122824039/o-direitoempresarial-atraves-dos-tempos>. Acesso em: 15. Ago. 2015.

BULOS, Uadi Lammêgo. Constituição federal anotada. São Paulo: Saraiva, 2007.

CAMPINHO, Sérgio. O direito de empresa à luz do novo código civil. Rio de Janeiro: Renovar, 2009.

COELHO, Fábio Ulhoa. Manual de direito comercial. São Paulo: Saraiva, 2014.

COMETTI. Marcelo Tadeu. Empresário e comerciante: direito comercial e direito empresarial: apenas uma diferença terminológica? Disponível em: $<$ http://www.jurisite.com.br/doutrinas/Comerciais/doutcom22.html $>$. Acesso em: 07. Ago. 2015.

DIAS, Maria Berenice. Manual de direito das famílias. São Paulo: Revista dos Tribunais, 2013.

FIÚZA, Ricardo. Novo código civil comentado. São Paulo: Saraiva, 2009. 
GONÇALVES, Carlos Roberto. Direito civil brasileiro. São Paulo: Saraiva, 2010.

Direito civil brasileiro: direito de família. São Paulo: Saraiva, 2012. GUIMARÃES, Marilene Silveira. Família e empresa: questões controvertidas (regime de bens e os reflexos dos arts. 977, 978 e 979 no direito de família). In: PEREIRA, Rodrigo da Cunha (coord.). Afeto, ética, família e o novo código civil. Belo Horizonte: Del Rey, 2004.

GUSMÃO, Mônica. Curso de direito empresarial. 5. ed. Rio de Janeiro: Lumen Juris, 2007.

MACHADO, Antônio Cláudio da Costa. Código civil interpretado. Barueri: Manole, 2015.

MAMEDE, Gladston. Empresa e atuação empresarial. São Paulo: Atlas, 2004.

MANFRÉ, José Antônio Encinas. Regime matrimonial de bens no novo código civil. São Paulo: Juarez de Oliveira, 2003.

MARTINS, Fran. Curso de direito comercial. Atualizado por Carlos Henrique Abrão. Rio de Janeiro: Forense, 2006.

MEDEIROS, Luciana Maria de. Evolução histórica do Direito Comercial. Da comercialidade à empresarialidade. Revista Jus Navigandi, Teresina ano 16, n. 2746, 7 jan. 2011. Disponível em: <http://jus.com.br/artigos/18219>. Acesso em: 11 ago. 2015.

PEREIRA, Caio Mário da Silva. Instituições de direito civil: direito de família. Rio de Janeiro: Forense, 2004.

QUEIROZ, Rafael Mafei Rabelo; FEFERBAUM, Marina. Metodologia jurídica: um roteiro prático para trabalhos de conclusão de curso. 1. ed São Paulo: Saraiva, 2012.

REQUIÃO, Rubens. Curso de direito comercial. 25. ed. São Paulo: Saraiva, 2003.

. Curso de direito comercial. 30. ed. São Paulo: Saraiva, 2011.

RODRIGUES, Sílvio. Direito civil: direito de família. São Paulo: Saraiva, 2004.

SALES. Albaniza Irani. Administração \& RH. Módulo 1. Recife: DataSul Cursos Profissionalizantes, 2007. Disponível em: <http://www.cairu.br/biblioteca/arquivos /Administracao/Administracao_RH_Modulo_I.pdf>. Acesso em 10. mar. 2015. 
SANTOS, Francisco Cláudio de Almeida. O pacto antenupcial e a autonomia privada. Disponível em: <oai:bdjur.stj.jus.br:2011/2589>. Acesso em: 15. Ago. 2015. 
